\title{
Effect of School Heads' Inspirational Motivation Leadership Practices on Students Academic Achievement in Public High Schools in Kumasi Metropolitan, Ghana
}

\author{
Samuel Gyansah ${ }^{1^{*}} \quad$ Martin Ogola $^{2} \quad$ Hellen Guantai ${ }^{2}$ \\ 1.University of Cape Coast, College of Distance Education, Private Mail Bag, Cape Coast, Ghana \\ 2. Kenyatta University, Department of Educational Management, Policy and Curriculum Studies
}

\begin{abstract}
Inspirational motivation leadership behaviour among school heads is critical in shaping students behaviour in a school context. This has aroused scholarly interest globally. The objective of this study was to assess the effect of school heads' inspirational motivation leadership practices on students' academic achievement in public high schools in Kumasi metropolitan, Ghana. The study adopted the transformational leadership theory espoused by James McGregor Burns (1978) and supported by Bass (1985). The convergent parallel design, a strand of the mixed methods approach was engaged for this study. The target population was 17370, and consisted of 19 heads of schools, 2122 teachers, and 15229 students. This study on the basis of Slovin's sample calculation formula, sampled 424 teachers and 552 students from the 19 schools selected. The study further employed Kothari's proportional representation method to determine sample size for teachers and students for each school. The study used random sampling technique to sample students and teachers from the schools. Data were collected with questionnaire and interviews. Experts in Educational Management were requested to address the content validity of the data collection instruments for the study. Cronbach's Alpha test showed that the instruments were reliable. Descriptive and inferential statistics were used to analyse the quantitative data. In descriptive statistics, frequency, weighted average, standard deviation, and percentages were used. Ordinary least square (OLS) regression analysis was employed to determine the effect of the independent variables on the dependent variable. The study controlled for factors that could influence students' academic achievement, these included sex of student, family structure of student, average age of teachers in a school, sex of teachers for a school, average educational attainment of teachers in a school, average teachers' rank in a school, and average number of years teachers have spent in a school. Analysed quantitative data was presented in tables. Qualitative data were analysed thematically and presented in narratives and in verbatim forms. The study used 5\% significance level. The study concluded that inspirational motivation leadership behaviours of school heads had significant positive effect on students' academic achievement. The study recommends that school heads should adopt this transformational leadership practice to ensure improvement in students' academic achievement.
\end{abstract}

Keywords: Inspirational motivation, Transformational leadership, School head.

DOI: $10.7176 / \mathrm{JEP} / 11-14-09$

Publication date:May $31^{\text {st }} 2020$

\subsection{Introduction}

School leadership is crucial to students' academic achievement. On daily basis, school leaders are confronted with a myriad of challenges. They have staff issues, school improvement, instructional matters, budgetary cuts, structural changes, and parents' concerns to deal with. In addition, school leaders are tasked with improving the academic achievement of all students (Hildebrand, 2012; Hughes \& Jones, 2010-2011). Though the school leader is not directly involved in the delivery of instruction, his supportive, collegial, and not over restrictive behaviours can have a positive effect on students' academic achievement (Tschannen-Moran \& Tschannen-Moran, 2011). This is corroborated by Hallinger (2010) when he posited that school heads through their behaviours that build collaborative learning structures and cultures and the development of staff and community leadership capacities have indirect or mediated positive effects on students' academic achievement. School leaders know that their effectiveness is most times judged by student performance as measured by test scores.

Transformational leadership model is popular in the literature as one with the capacity to bring about success to schools. This model of leadership has become prevalent in the field of education administration and it is noted to be relevant to confront present challenges in school administration that heads of secondary schools have to contend with(Bush, cited in Berkovich, 2016). The researchers in this study engaged the convergent mixed methods design to analyse the effect of inspirational motivation leadership practices of heads of SHS on students' academic achievement.

Inspirational Motivation school leaders behave in ways that motivate and inspire those around them by providing meaning to teachers and students' work. Indicators of this leadership practice that this study focused on included the practices of building and sharing vision with subordinates, demonstrating a sense of confidence in the followers, committing to high standards at the workplace, and encouraging team work (Asare, 2016; Osagie \& 
Momoh, 2013; Mendels, 2012). Motivation is fundamental because it assists to sustain behaviours that focus on improvement. The High school head exercises his or her leadership roles with and through teachers, non-teachers, and students to realize set targets and this can be done through inspirational motivation. Teachers feel motivated to teach and students feel motivated and encouraged to learn when the school head maintains an enabling environment for learning, shares and develops the vision of the school with teachers and students, encourages team spirit, shows appreciation to good works done by followers, demonstrates confidence in the capacity of followers to perform, and initiate organizational change(Northouse, 2016). This behaviour when practiced has the ability to bring about improved students' academic achievement.

Academic achievement of students has become so topical that it has prompted a lot of scholars to work hard to untangle factors that militate against good academic achievement. It has attracted the attention of parents, policymakers, and planners. The major goal of the school is to ensure that students succeed academically (Adeyemo cited in MeenuDev, 2016). Academic achievement is crucial when assessing the success of an individual student and has the capacity to determine key life outcomes such as income and health, (Briley et al, cited in Bosman, 2015). Virtually everybody concerned with education places premium on sound scholarship.

Academic achievement connotes performance outcomes that show the extent to which a student has accomplished goals that were the focus of activities in instructional environments, specifically in school, college, and university (Steinmayr et al, 2015), as a measure of success it is related to the knowledge and skills developed by a student in various courses. Academic achievement plays an important role in the life of an individual. The individual who is academically deficient is limited as far as progression in school is concerned, and more, his future income and productivity is negatively affected,(Kasirye cited in Bosman, 2015). The consequence on the individual can be disastrous as he is likely to experience unemployment, substance use and delinquency as adults. He becomes a potential burden to himself, the family, and the community at large. It is therefore critical to examine the potential determinants of a student's academic success so as to deter him from becoming a burden to himself and the community.

\subsection{Methodology}

The convergent parallel design belonging to the mixed methods research approach was used for this study. The main reason for choosing this design was to obtain different but complementary data on the same topic to best understand the research problem. The complementary data came from quantitative and qualitative strands of the study(Creswell \& Plano 2011; Fraenkel et al, 2012). This mixed methods research design enabled a deeper understanding of the behaviours of heads of High schools in their efforts to improve students' academic achievement. This would have been difficult to realize if a single quantitative or purely qualitative design had been adopted. Another reason for opting for this design was that it offered the opportunity to develop better, more context specific instruments (Creswell, 2007).

The variables of the study were grouped into three as dependent variable, independent variables, and controlled variables. The dependent variable in this study is academic achievement. The study measured academic achievement in line with the thoughts ofVidoni\& Grassetti (2008)and Dhuey \& Smith (2012). In these empirical studies, test scores were used. This study measured academic achievement as the average academic performance of a student over one academic year (2017/2018). An academic year in Ghana as at 2017/2018 academic year was three terms, hence average score for core subjects for the three terms were used as students' academic achievement.

The independent variable in this study is one of the four components of transformational leadership model. Bass, (1985) had identified four main components of transformational leadership as idealized influence, inspirational motivation, intellectual stimulation, and individualized consideration, each with different attributes constituting the leadership behaviours of heads of schools. This study therefore on the basis of Bass (1985) has one of the four components of transformational leadership model as independent variable.

Aside transformational leadership practices of school heads, other factors have been found to influence academic achievement of students. These factors include, sex of student (MeenuDev, 2016; Rabjay, 2018), parenting of students (Bosman, 2012), teacher characteristics (examples, sex, age, educational attainment, rank, and number of years spent in a school) [Kimani et al, 2013]. These are used as the intervening/control variables of this study and were controlled statistically. 
Table 1: Descriptions of Variables

\begin{tabular}{|c|c|c|}
\hline $\begin{array}{l}\text { Type } \\
\text { variable }\end{array}$ & Variables & Descriptions \\
\hline $\begin{array}{l}\text { Dependent } \\
\text { Variables }\end{array}$ & $\begin{array}{l}\text { Student's } \\
\text { achievement }\end{array}$ & $\begin{array}{l}\text { This is the average academic performance of a student } \\
\text { over one academic year }(2017 / 2018) \text { academic year })\end{array}$ \\
\hline $\begin{array}{l}\text { Independent } \\
\text { Variable }\end{array}$ & Inspirational motivation & $\begin{array}{l}\text { The weighted average of all the } 15 \text { items under } \\
\text { inspirational motivation of a headmaster in a school }\end{array}$ \\
\hline
\end{tabular}

Controlled Sex of student

Variables

Parenting of student

Sex of teachers in a school

Age of teachers in a school (numeric)

Educational attainment of teachers for a school (numeric) Rank of teachers in a school (numeric)

Working experience (numeric) Average number of years teacher have spent in a school

\section{Source: Author's own construct (2019)}

The main purpose of this study was to determine the effect of transformational leadership practice of inspirational motivation of heads of SHS on academic achievement of students in the Kumasi Metropolis. The relationship between this transformational leadership practice and students' academic achievement can be summarized on the basis of Gujarati and Porter (2003) as in equation 1.

$$
Y_{i}=\propto_{0}+\propto_{1} X_{i}+\varepsilon_{i} \ldots \ldots \ldots \ldots \ldots \ldots \ldots \ldots \text {. } \ldots \ldots \ldots \ldots
$$

Where the dependent variable Yi represents students' academic achievement, $\mathrm{X}$ is the vector of explanatory variables and $\varepsilon i$ is the error term. The model for the regression analysis aspect of this study which enabled a test of the null hypothesis: there is no statistically significant effect of heads of schools inspirational motivation leadership practices on students' academic achievement in public senior high schools in Kumasi metropolitan is:

$$
\begin{gathered}
A C A A H_{i}=\propto_{0}+\propto_{1} \text { INSMOT }_{i}+\propto_{2} \text { SEXSTD }_{i}+\propto_{3} \text { FAMST }_{i}+\propto_{4} \text { SEXTE }_{i}+\propto_{5} \text { AGETE }_{i}+\propto_{6} \text { EDUTE }_{i} \\
+\propto_{7} \text { NYTE }_{i}+\propto_{8} \text { RANTE }_{i}+\varepsilon \ldots \ldots \ldots \ldots
\end{gathered}
$$

The sampling frame or target population which was made of individuals with shared identifiable features (Creswell, 2012) was all the heads of the 19 public SHS, all the teachers in the 19 schools and all the third year students in the 19 schools in Kumasi metropolis. All the 19 public SHS whose final examinations are conducted by WAEC in the Metropolitan constituted the target population for the study. The teachers, the form three students, and the heads of the 19 SHS were targeted for the study. The teachers were part of this study because they were closely related to the school heads as far as school activities were concerned and were therefore expected to be in a better position to tell and explain the leadership behaviours of the school heads. The form three students were chosen for this study because having stayed in the school for three years; they knew their school heads that much and could tell how the school heads went about some aspects of their work and as such were expected to give objective impressions about their school heads' leadership behaviour. The school heads were part of the study because their position confers on them the leadership of the school. They were in charge of the day to day administration of the school and were directly responsible for the well-being or otherwise of the schools. It was their leadership behaviours that constituted the independent variables of this study.

The census sampling technique was adopted to select all the 19 public SHS and the 19 heads of the schools in the study locale for the study. The census technique was used because the study aimed to collect the views of all the heads of the schools. Again, the census was engaged because the heads of schools were not that many for elements to be sampled from. Kothari (2013) endorses the use of the census approach when he suggests that it is an applicable method in research situations where the population is not large enough to be sampled, where there is enough time to collect data and where there is the need for high accuracy. Moreover, based on the personal judgment of the researcher, the 19 schools and the 19 school heads constituted the appropriate avenues and subjects to provide the data needed for the study. (Fraenkel, Wallen, \& Hyun, 2012). The Slovin's sample calculation formula (Amin, 2005)was used to arrive at the sample size for teachers and students. This formula was deemed suitable because the size of the population was known. The formula for determining the sample size is given as follows: 
$\mathrm{n}=\mathrm{N} /(1+\mathrm{Ne} 2)$

Where $\mathrm{n}$ is the Sample

$\mathrm{N}$ is the population

$\mathrm{e}$ is the margin of error $(0.05)$

To arrive at the number of teachers and students to select from each of the 19 schools, the proportional allocation method of Kothari (2013) was then used. The formula is as follows:

ni=n.Pi

Where ni is= the size of the strata, $\mathrm{n}=$ the sample size, $\mathrm{Pi}=$ the proportion of the strata in the target population.

After the proportional allocation formula was applied and the numbers for teachers and students from the specific schools had been arrived at, the simple random sampling technique was engaged to select the teacher and student participants for the study from the various schools. This technique was adopted to give every member of the population an equal and independent chance of being selected, thereby giving a representative sample of the population for the study(Fraenkel et al, 2012). Using these formulae, and sampling technique, the sample size for teachers was 424 and the sample size for students was 552.

Purposive sampling was used to select, teachers and students to be interviewed to satisfy the qualitative strand of the study. Teachers and students were selected based on their responsibilities and experience. One assistant to the head of the school and the longest serving head of department were selected in each school and interviewed. The school prefect or his or her assistant were selected for interview in each school. The census technique was used to select heads of schools. These modes of selection were based on the researcher's judgment (Fraenkel et al, 2012).

Questionnaires, which were designed to measure recognizable behaviours (Yukl, 2013) were used to collect data from the teachers and students. The researcher ensured that items on the questionnaire were clear and unambiguous. A Likert scale measuring the participants' views toward the heads leadership practices and how they affected students' academic achievement was constructed. The items of the questionnaire were based on the unpacked aspects of the independent variables. This study made use of qualitative survey interviews. In this, openended questions without response options were asked and responses recorded (Creswell, 2012). The use of the interview in this study helped to bring out the practices, actions, and beliefs of school heads and revealed a comprehensive view of school heads' transformational leadership practices (Mwangi, 2016). Interviews were conducted on the 19 school heads, 38 teachers, and 19 students to tap information relevant to the study. The narratives from them served the desired purpose to validate the findings from the quantitative strand. The structure of the interview guide was based on the elements of leadership practices identified under the independent variable. The study also made use of some school records. For example, the official document that contained the names of teachers in the school with their academic qualifications, ranks, educational qualification and age was taken to extract information needed for the study. In some instances, it served to cross check information supplied by the heads and teachers on the instruments. In the event where there was a contradiction, the head or teacher in question was approached for clarification. For the results of students for the academic year, (2017/2018) some schools supplied them to the researcher in hard copy and some few supplied by giving the schools' website where the results was fetched.

To ensure content validity, there was the need to have expert view on the design of research instruments. The researcher submitted questionnaire to his supervisors who are educational leadership experts to scrutinize to ensure the required scope of transformational leadership was covered. Each item on the questionnaire formulated was matched with the objectives of the study to ensure that the items were directly related to the main themes in the objectives; hence the questionnaire adequately covered the scope of the phenomena under study. In relation to the qualitative strand of the study, validity was ensured by religiously adopting the design and methods chosen for the study, which had the capacity to make the findings trustworthy and dependable(Simon \& Goes, n.d.). To test for reliability, the researcher pre tested the questionnaire in SIMMS SHS on teachers, students and headmaster and assistant headmasters/mistresses. After, the pre-test, the researcher made changes to some few items which were identified as unclear and leading questions by the pre-test respondents. The study further pre-tested the instrument in Kofi Agyei SHS and the responses obtained were not different from those obtained from SIMMS SHS.

The study moreover, tested for reliability of final instruments for data collection. The actual data were entered into statistical software called Statistical Package for Social Scientist (SPSS) version 21.0 and used Cronbach's Alpha test to test for reliability of statements (items) under each component of transformational leadership. According to Cronbach (1951), Cronbach's Alpha value of 0.7 is an indication of reliability of an instrument. Reliability in connection with the qualitative strand of the study was established by adopting member-checking. Forty-six participants, constituting $60 \%$ interviewed were tasked to review the audio responses that had been transcribed to check if they conformed to what transpired during the interview section. The composition of the 46 was 9 heads of schools, 9 teachers and 28 students. In addition, the uniformity of responses confirmed the interview questions were reliable (Simon \& Goes, n.d.). 


\subsection{FINDINGS AND DISCUSSION}

The objective of the study was to assess the effect of heads of schools inspirational motivation leadership practices on students' academic achievement. Specific statements related to headmasters/headmistress' inspirational motivation leadership practices were posed and respondents were asked to express the extent of agreement or disagreement to each statement as applied to their schools. The responses were on a five Likert Scale ranging from Strongly Disagree (SD) [1] to Strongly Agree (SA) [5]. The analysis was done using weighted average of the responses and their standard deviations. Weighted average of 3.50-5.00 indicates agreement to a statement while a range of 1.00-1.49 indicates disagreement to a statement. Specifically, weighted average of 1.00-1.49 represents strongly disagree; 1.50-2.49 represents disagree; 2.50-3.49 represents neutral; 3.50-4.49 represents agree and 4.505.00 represents strongly agree. Upon this basis and supported by Joshi, Kale, Chandel, \& Pal (2015) the interpretations of the study were made. The study analysed the responses using weighted average (WA) and standard deviation. This study further compared the responses of teachers and students using Independent Samples T-test as shown in Table 2

Table 2: Teachers' and Students' responses to the effect of School Heads Inspirational Motivation Leadership Practices on Students' Academic Achievement

\begin{tabular}{|c|c|c|c|c|c|c|c|c|c|}
\hline \multirow[t]{2}{*}{ Statements } & \multirow{2}{*}{$\begin{array}{l}\text { Type of } \\
\text { Respondents }\end{array}$} & \multicolumn{5}{|c|}{ RESPONSES } & \multirow[t]{2}{*}{ WA } & \multirow{2}{*}{$\begin{array}{l}\text { Std. } \\
\text { Dev. }\end{array}$} & \multirow{2}{*}{$\begin{array}{l}\mathrm{P}- \\
\text { value }\end{array}$} \\
\hline & & $\mathrm{SD}$ & $\mathrm{D}$ & $\mathrm{N}$ & $\mathrm{A}$ & SA & & & \\
\hline $\begin{array}{l}\text { Recognizes and celebrates } \\
\text { school's }\end{array}$ & Teachers & $\begin{array}{l}8 \\
(2.5)\end{array}$ & $\begin{array}{l}20 \\
(6.2)\end{array}$ & $\begin{array}{l}46 \\
(14.3)\end{array}$ & $\begin{array}{l}185 \\
(57.5)\end{array}$ & $\begin{array}{l}63 \\
(19.6)\end{array}$ & 3.8540 & 0.8898 & 0.321 \\
\hline $\begin{array}{ll}\text { accomplishments } & \text { and } \\
\text { acknowledge failures } & \end{array}$ & Students & $\begin{array}{l}33 \\
(6.5)\end{array}$ & $\begin{array}{l}38 \\
(7.5)\end{array}$ & $\begin{array}{l}76 \\
(14.9)\end{array}$ & $\begin{array}{l}147 \\
28.9)\end{array}$ & $\begin{array}{l}215 \\
(42.2)\end{array}$ & 3.9314 & 1.2046 & \\
\hline $\begin{array}{l}\text { Talks enthusiastically } \\
\text { about the academic }\end{array}$ & Teachers & $\begin{array}{l}6 \\
(1.9)\end{array}$ & $\begin{array}{l}13 \\
(4.0)\end{array}$ & $\begin{array}{l}35 \\
(10.9)\end{array}$ & $\begin{array}{l}173 \\
(53.7)\end{array}$ & $\begin{array}{l}95 \\
(29.5)\end{array}$ & 4.0497 & 0.8560 & 0.01 \\
\hline $\begin{array}{l}\text { objectives of the school } \\
\text { that needs to be } \\
\text { accomplished }\end{array}$ & Students & $\begin{array}{l}9 \\
(1.8)\end{array}$ & $\begin{array}{l}24 \\
(4.7)\end{array}$ & $\begin{array}{l}58 \\
(11.4)\end{array}$ & $\begin{array}{l}149 \\
(29.2)\end{array}$ & $\begin{array}{l}270 \\
(52.9)\end{array}$ & 4.2686 & 0.9591 & \\
\hline $\begin{array}{l}\text { Ensures that staff members } \\
\text { enjoy working in }\end{array}$ & Teachers & $\begin{array}{l}15 \\
(4.7)\end{array}$ & $\begin{array}{l}33 \\
(10.2)\end{array}$ & $\begin{array}{l}89 \\
(27.6)\end{array}$ & $\begin{array}{l}132 \\
(41.0)\end{array}$ & $\begin{array}{l}53 \\
(16.5)\end{array}$ & 3.5435 & 1.0320 & 0.324 \\
\hline $\begin{array}{l}\text { groups/teams to enhance } \\
\text { teaching and learning }\end{array}$ & Students & $\begin{array}{l}20 \\
(3.9)\end{array}$ & $\begin{array}{l}60 \\
(11.8)\end{array}$ & $\begin{array}{l}137 \\
(26.9)\end{array}$ & $\begin{array}{l}171 \\
(33.5)\end{array}$ & $\begin{array}{l}122 \\
(23.9)\end{array}$ & 3.6176 & 1.0897 & \\
\hline $\begin{array}{l}\text { Secures staff consent in } \\
\text { important issues that }\end{array}$ & Teachers & $\begin{array}{l}30 \\
(9.3)\end{array}$ & $\begin{array}{l}34 \\
(10.6)\end{array}$ & $\begin{array}{l}83 \\
(25.8)\end{array}$ & $\begin{array}{l}131 \\
(40.7)\end{array}$ & $\begin{array}{l}44 \\
(13.7)\end{array}$ & 3.3882 & 1.1335 & 0.000 \\
\hline $\begin{array}{lr}\text { connect } & \text { students' } \\
\text { performance } & \text { before } \\
\text { implementation } & \end{array}$ & Students & $\begin{array}{l}21 \\
(4.1)\end{array}$ & $\begin{array}{l}41 \\
(8.0)\end{array}$ & $\begin{array}{l}122 \\
(23.9)\end{array}$ & $\begin{array}{l}156 \\
(30.6)\end{array}$ & $\begin{array}{l}170 \\
(33.3)\end{array}$ & 3.8098 & 1.1095 & \\
\hline $\begin{array}{l}\text { Has confident that staff and } \\
\text { students will accomplish }\end{array}$ & Teachers & $\begin{array}{l}5 \\
(1.6)\end{array}$ & $\begin{array}{l}20 \\
(6.2)\end{array}$ & $\begin{array}{l}56 \\
(17.4)\end{array}$ & $\begin{array}{l}184 \\
(57.1)\end{array}$ & $\begin{array}{l}57 \\
(17.7)\end{array}$ & 3.8323 & 0.8445 & 0.01 \\
\hline challenging academic goals & Students & $\begin{array}{l}18 \\
(3.5)\end{array}$ & $\begin{array}{l}23 \\
(4.5)\end{array}$ & $\begin{array}{l}82 \\
(16.1)\end{array}$ & $\begin{array}{l}175 \\
(34.3)\end{array}$ & $\begin{array}{l}212 \\
(41.6)\end{array}$ & 4.0588 & 1.0359 & \\
\hline $\begin{array}{l}\text { Consults } \\
\text { representatives on issues }\end{array}$ & Teachers & $\begin{array}{l}4 \\
(1.2)\end{array}$ & $\begin{array}{l}29 \\
(9.0)\end{array}$ & $\begin{array}{l}89 \\
(27.6)\end{array}$ & $\begin{array}{l}143 \\
(44.4)\end{array}$ & $\begin{array}{l}57 \\
(17.7)\end{array}$ & 3.6832 & 0.9098 & 0.116 \\
\hline $\begin{array}{l}\text { relating to academic } \\
\text { progress of students }\end{array}$ & Students & $\begin{array}{l}59 \\
(11.6)\end{array}$ & $\begin{array}{l}57 \\
(11.2)\end{array}$ & $\begin{array}{l}90 \\
(17.6)\end{array}$ & $\begin{array}{l}147 \\
(28.8)\end{array}$ & $\begin{array}{l}157 \\
(30.8)\end{array}$ & 3.5608 & 1.3353 & \\
\hline $\begin{array}{l}\text { Ensures that he is } \\
\text { understood by teachers and }\end{array}$ & Teachers & $\begin{array}{l}15 \\
(4.7)\end{array}$ & $\begin{array}{l}42 \\
(13.0)\end{array}$ & $\begin{array}{l}62 \\
(19.3)\end{array}$ & $\begin{array}{l}153 \\
(47.5)\end{array}$ & $\begin{array}{l}50 \\
(15.5)\end{array}$ & 3.5621 & 1.0490 & 0.013 \\
\hline $\begin{array}{l}\text { students in whatever he } \\
\text { does that relates to the } \\
\text { academic progress of } \\
\text { students }\end{array}$ & Students & $\begin{array}{l}32 \\
(6.3)\end{array}$ & $\begin{array}{l}43 \\
(8.4)\end{array}$ & $\begin{array}{l}106 \\
(20.8)\end{array}$ & $\begin{array}{l}165 \\
(32.4)\end{array}$ & $\begin{array}{l}164 \\
(32.2)\end{array}$ & 3.7569 & 1.1726 & \\
\hline $\begin{array}{l}\text { Exhibits commitment to } \\
\text { the academic goals of the }\end{array}$ & Teachers & $\begin{array}{l}5 \\
(1.6)\end{array}$ & $\begin{array}{l}16 \\
(5.0)\end{array}$ & $\begin{array}{l}49 \\
(15.2)\end{array}$ & $\begin{array}{l}155 \\
(48.1)\end{array}$ & $\begin{array}{l}97 \\
(30.1)\end{array}$ & 4.0031 & 0.8913 & 0.004 \\
\hline school & Students & $\begin{array}{l}18 \\
(3.5)\end{array}$ & $\begin{array}{l}20 \\
(3.9)\end{array}$ & $\begin{array}{l}63 \\
(12.4)\end{array}$ & $\begin{array}{l}151 \\
(29.6)\end{array}$ & $\begin{array}{l}256 \\
(50.2)\end{array}$ & 4.3941 & 3.3416 & \\
\hline $\begin{array}{l}\text { Aligns individual goals } \\
\text { with the goals of the school }\end{array}$ & Teachers & $\begin{array}{l}7(2.2) \\
30\end{array}$ & $\begin{array}{l}38 \\
(11.8)\end{array}$ & $\begin{array}{l}98 \\
(30.4)\end{array}$ & $\begin{array}{l}138 \\
(42.9)\end{array}$ & $\begin{array}{l}41 \\
(12.7)\end{array}$ & 3.5217 & 0.9345 & 0.099 \\
\hline & Students & $(5.9)$ & $\begin{array}{l}56 \\
(11.0)\end{array}$ & $\begin{array}{l}126 \\
(24.7)\end{array}$ & $\begin{array}{l}152 \\
(29.8)\end{array}$ & $\begin{array}{l}146 \\
(28.6)\end{array}$ & 3.6980 & 1.7504 & \\
\hline
\end{tabular}

Source: Field Data (2019); where $S D=$ strongly disagree; $D=$ disagree; $N=$ neutral; $A=$ agree; $S A=$ strongly agree; WA=weighted average; Std. Dev. =standard deviation

The results in Table 2 show that the respondents (teachers and students) expressed agreement to most of the items of inspirational motivation practices thereby supporting Pongpearchan's (2015) description of a transformational leader as one who shares his or her vision and involves followers in organizational processes in order to inspire efficiency and effectiveness in the performance of duties.

The weighted averages of 3.8 and 3.9 for teachers and students respectively on the heads of schools conduct 
of recognizing and celebrating schools' academic accomplishments and acknowledging failures reveal a high rating therefore indicating a practice that inspires and motivates teachers and students to perform their varied tasks of teaching and learning as expected. This behaviour of recognizing and celebrating academic accomplishments goes a long way in motivating students and teachers. Students who observe colleagues mentioned and awarded on Open Days endeavour to work hard to be awarded and this has positive impact which arouses the interest to learn. Teachers who see their students awarded become happy and are motivated to work harder for more of such awards. In a meta-analysis study, Orhan-Ozen (2017) reveals that there is a positive relationship between motivation and student achievement. Orhan-Ozen (2017) establishes in his study an effect size of .27 of motivation on student achievement, indicating that motivation has a low level effect on students' achievement.

In Ghana, it is not uncommon to find heads of SHS trumpeting the school's achievement during an academic year at Speech and Prize Giving Days. During such momentous occasions, heads of SHS who go further to highlight the challenges of the school that relate to teaching and learning are seen as bold and sincere leaders, leaders who are prepared to share the vision of the school with stakeholders within and outside the school community, a real mark of a transformational leader.

There is evidence from Table 2 that teachers and students rated the behaviour of talking enthusiastically about the academic objectives of the school that need to be accomplished as high. Experience gained in the GES shows that where school leaders continuously hammer on what is to be achieved, followers tend to behave in tune to what is being hammered to bring about the realization of educational goals of the school. The weighted average of 4.0 for teachers and 4.3 for students is a solid agreement that such practice inspires and motivates teachers and students.

The endorsement of the support for teamwork from the head of school by teachers (3.5) and students (3.6) as an appropriate behaviour that gingers inspiration and motivation is a finding that is in congruence with Asare (2016). In a study conducted in Ghana which sought to gain in-depth knowledge about the experiences of Basic school teachers in relation to their perceptions about the leadership behaviours of their headteachers, Asare (2016) asserts that schools' heads inspirationally motivated teachers by instituting team work in schools through the formation of committees. Committee work is a common feature in the administration of SHS in Ghana. In most SHS, there are Examination, Time Table, Disciplinary and other Committees. There are instances where ad hoc committees are constituted to manage events and development programmes of the school. Teachers and in some cases students constitute the membership of such committees. In all this, leadership is shared and the end result is inspiration and motivation to work hard to realize goals set by the school. This finding also agrees with the description of inspirational motivation leader in a study on transformational leadership and school outcomes in Kenya(Ayiro, 2014). In this study, Ayiro (2014) contends that an inspirational motivation leader stands for team spirit, provides meaning and challenge to the work at hand and develops an atmosphere of commitment to goal and a shared vision.

The demonstration of confidence in teachers and students to accomplish challenging academic goals is rated high by teachers (3.8) and students (4.1). Confidence is crucial in effective leadership. It takes a self-confident leader to have confidence in others. Self-confidence is a trait that permits individuals to possess positive yet realistic views of themselves and their situations (Tripathy \& Srivastava, 2012). When a leader exhibits confidence, it makes it easier to trust that leader, and people want to work with leaders they trust. Followers become energized when they realize confidence is placed in them. Such energy begets motivation and inspiration. Therefore, a school head that is confident believes his teachers and students can perform exhibits the transformational leader quality of inspirational motivation needed for students' academic achievement to thrive.

The role of self confidence in enticing followers to act appropriately to suit leadership achieve desired targets had been studied for some time in social psychology, marketing, and management(Bandura, 1977; Chemers et al., 2000 as cited in Greenacre, Tung \& Chapman, 2014). Research establishes that leaders, who are self-confident and believe in their abilities and opinions, guide and manage followers effectively (Bandara, 1988; Luthans \& Peterson, 2002; Schyns \& Sczesny, 2010, as cited in Greenacre et al., 2014). In two different studies, one a survey and the other an experiment in the United States, to examine whether self-confidence lead to the influence of followers, Greenacre et al (2014) establish that leaders with confidence generally have the ability to influence and inspire their followers. This supports the finding of the study that confidence of the leader is a practice needed to inspire and boost performance of followers.

In a typical quantitative analysis, Owens and Keller (2018) posit that confidence is a critical factor that affects performance, adding that the absence of confidence has been linked with failure. The objective of their study was to examine workforce confidence in the patient experience and patient perceptions of their experience of care; a survey study that covered 41 United states hospitals. The key conclusion of their study was that confidence was an important characteristic of the healthcare workforce, connecting appropriately to the finding of this current study that confidence is vital to inspire teachers and students work hard to realize deserved students' academic achievement.

The high ratings on the practices of consulting students' representatives on issues relating to academic progress, with teachers (3.7), students (3.6) weighted averages and ensuring staff involvement in the decision 
making process, with teachers (3.5) and students (3.9) are in tune with Boateng (2012) when he asserts in a quantitative study in an Adventist University in Ghana, that when followers are involved in crafting the vision of the school, they tend to own the processes and activities that are undertaken to ensure improvement in the organization. Consultation and involvement in the building and sharing of the vision of the school are crucial in enhancing the interest of followers in an organization's goals. The head of the school should endeavour to improve the cultures of teaching, learning and achievement in their school and a sure way of doing this is having students and teachers as part of almost all key decisions of the school.

In a qualitative study approach in the Institute of Education at the International Islamic University in Malaysia, using a semi-structure interview to gather data to establish the link between decision-making and leadership styles, Kayode, Mojeed, \& Fatai (2014) found that leadership and decision-making are linked in practice and the preferred leadership and decision making styles are the participatory leadership and consultative decision-making approach. The main conclusion of their study is that this link ensures proper leader-follower relationship and employee performance, tying in so well with the finding of this current study that a premium is placed on participatory leadership and consultative decision-making approach as a leadership practice that has the capacity to affect students' academic performance positively.

The finding on consulting students' representatives on issues relating to academic progress renders the ratings on securing staff consent in important issues that connect students' performance before implementation interesting. The weighted average of teachers is 3.4, while that of students is 3.8. This difference in opinions is buttressed by a view expressed by a teacher in an interview in one of the schools. He stated:

The headmaster forgets that he cannot be a master of all the subjects and surprisingly refuses to consult heads of departments to know what the current trends in curriculum are. By this, he is discouraging teachers and it is affecting teachers' delivery in the classrooms.

Again in a school, a student in an interview revealed that the head of the school even consulted students more than the teachers on some critical issues that pertain to students' academic achievement. The student stated:

The headmaster's fine attitude to the students is good and bad. Good as it makes him approachable to the students but bad in the sense that teachers in the school are aggrieved by this behaviour of the headmaster and it is affecting their delivery in the classrooms.

The researcher is of the strong belief that the ability to lead is dependent on others and the relationship or networks leaders cultivate and so school leaders must create the necessary conditions for this belief of the researcher of this current research to hold.

Aligning goals of the individual to goals of the educational institution is critical to inspire and motivate teachers and students to aspire to achieve the educational goals of the school. Teachers with a weighted average of 3.5 and students with the weighted average of 3.7 agree to the statement that aligning individual goals to school goals as a practice promotes performance. The school head who engages in this practice is likely to be aware of the fact that when organizational rules and personal values are congruent the individual is more satisfied and works hard to achieve success. Alignment is an important strategy to build and sustain performance. This, the head of the school can achieve through focusing upon the quality of learning and teaching while at the same time raising the levels of individual and collective efficacy and involvement of teachers and students. This finding conforms withCruickshank's (2017)position when he posits in a study done in Australia on the influence of school leadership on student outcomes that the principal must motivate followers to the point that their personal goals are one and the same with the school goals. According to Cruickshank (2017) when the head of the school fails in this, school goals will have little motivational value for students and teachers thereby leading to poor performance by students and teachers.

On the issue of exhibiting commitment to the academic goals of the school, most teachers, and $252(78.2 \%)$ indicated that their headmasters/headmistresses were committed to the goals of the school. Students also shared the same view with most, 407 (78.8\%) showing agreement. This exhibition of commitment to academic goals is expected to lead to improvements in the school which subsequently will yield appropriate students' academic achievement. The weighted averages of 4.0 and 4.4 for teachers and students respectively are an indication that premium was placed on this practice as a way of inspiring and motivating teachers and students to perform to realize required students' academic achievements. The interview segment of the study confirmed this finding. In one of the schools a teacher stated:

The headmaster's love for his work, dedication, his punctuality and regularity at work is infectious and if you are a teacher or student in this school, you cannot afford to be lazy. I am not surprised that the results of the school are very good.

The head of the school should be a reflection of what he wants students and teachers to be. A head of school who exhibits commitment will naturally affect teachers and students with commitment to the academic goals of the school. There is a generally accepted belief that the existence of commitment is positive for both workers and the organization, since having committed employees will allow better achieve the objectives. A research study conducted in England to examine the relationship between leadership and improvements in students' outcomes 
revealed that the headteachers' commitment hence his/her leadership constitute a major pillar for sustained effectiveness and improvements in the school (Day \& Sammons, 2015) and this research fully supports the findings indicated in this current study.

A headmaster of a school stated:

I am the first person to come to the office. In a day, at least, I go round the classrooms two times to check if classes are going on. I have assigned myself a class where I teach English language. I make sure I don't miss my class. If administrative matters should make it difficult to attend a class, I either arrange with a teacher to stand in for me or I arrange with the students and we meet for the class at a time conducive for both students and $I$.

Table 2 reveals that most teachers, $203(63 \%)$ and most students, $329(64.6 \%)$ indicated that the headmasters' actions were clearly understood so far as they related academic progress of students, revealing the significance of communication in the school set up. This leadership practice is encouraging enough as it has the capacity to stimulate teachers and students to do what is expected to realize the needed students' academic achievement. However, in a particular school, an interview with students revealed something that contrasts the view expressed by most teachers and students. A student in a one school expressed:

We do not even know if our headmaster is a businessman or head of the school. For most times he is not in the school and certainly his leadership actions are difficult to understand and this is affecting our academic work.

It is therefore not surprising that 106 students, representing $20.8 \%$, expressed neutrality and 75 students, representing $14.7 \%$, totally disagreed with the view expressed in the statement. However, the weighted averages indicate agreement to the view expressed in the statement by most teachers (3.6) and most students (3.8). This finding is fully supported by a study carried out in Nigeria (Amanchukwu, Stanley, \& Ololube, 2015) to examine the wider context of leadership and its effectiveness towards improving school management which cited the United States Army (1983) principles of leadership and reveals that communication is vital in inspiring and motivating. The head of the school, like the army commander, who is the leader, must ensure that tasks are understood, supervised, and accomplished. The leader of a school must communicate effectively.

To estimate the effect of inspirational motivation on students' academic achievement, the study determined the correlation between inspirational motivation leadership practices and students' academic achievement through Pearson's Correlation Coefficient (See Table 3) and test for serial collinearity with Tolerance and Variance Inflation Factor (See Table 4.)

Table 3: Pearson's Correlation Coefficient Matrix of Inspirational Motivation Leadership Practices and Students' Academic Achievement

\begin{tabular}{lll}
\hline & Academic achievement & Inspirational Motivation \\
\hline Academic achievement & 1.000 & $0.249^{* *}$ \\
Inspirational Motivation & & 1.000 \\
\hline
\end{tabular}

Source: Field Data (2019); ** Correlation is significant at 0.01 level (2-tailed)

FromTable 3, there is a significant positive correlation between inspirational motivation and students' academic achievement. This is an indication that as the headmaster's or headmistress' inspirational motivation leadership practices increases, students' academic achievement increases and vice versa.

To test for serial collinearity with Tolerance and Variance Inflation Factor to further estimate the effect of headmasters'/headmistress's inspirational motivation leadership behaviour on students' academic achievement, OLS regression was performed (See Table 4). The results inTable 4 show that there is no problem of serial collinearity since tolerance level and VIF are above 0.4 and below 3.00 respectively.

Table 4. OLS Regression of Effect of Inspirational Motivation Leadership Practices on Students' Academic Achievement

\begin{tabular}{llllllll}
\hline Variables & \multicolumn{2}{l}{$\begin{array}{l}\text { Unstandardized } \\
\text { Coeff. }\end{array}$} & Std Error & $\begin{array}{l}\text { Standardized } \\
\text { Coeff. }\end{array}$ & t-test & p-value & \multicolumn{2}{l}{$\begin{array}{l}\text { Collinearity } \\
\text { Tolerance }\end{array}$} & VIF \\
\hline Constant & -2.485 & 1.004 & - & -2.381 & 0.018 & - & - \\
Inspirational Motivation & 1.044 & 0.255 & 0.180 & 4.085 & 0.00 & 0.677 & 1.477 \\
\hline Number of Obs. & 510 & & & & & & \\
R & 0.581 & & & & & \\
R-square & 0.338 & & & & & & \\
Adj. R-square & 0.327 & & & & & & \\
F-statistic & 31.981 & & & & & & \\
P-value & 0.000 & & & & & & \\
\hline
\end{tabular}

\section{Source:Field Data (2019); Significant at 5\%; Dependent Variable=Academic Achievement}

The results in Table 4 show that inspirational motivation had significant positive impact on students' academic achievement with beta $=1.000$. This is an indication that a unit increase in headmasters'/headmistress' inspirational motivation leadership behaviour leads to 1.000 unit increases in students' academic achievement. 
This study thus rejects the null hypothesis which states that 'there is no statistically significant effect of heads of schools inspirational motivation leadership practices on students' academic achievement in public senior high schools in Kumasi metropolitan'. Therefore, there is statistically significant effect of heads of schools inspirational motivation leadership practices on students' academic achievement in public senior high schools in Kumasi metropolitan.

The adjusted R-square shows that the explanatory variables in this model put together explained $32.7 \%$ of the variation in academic achievement. The remaining $67.3 \%$ variation in students' academic achievement is explained by all other variables that could determine students' academic achievement but excluded in the model. The model as a whole is statistically ( $\mathrm{F}-\mathrm{stats}=31.981 ; \mathrm{p}=0.000)$ fit for predictions and forecasting.

\subsection{SUMMARY, CONCLUSION AND RECOMMENDATIONS}

The objective of the study was to estimate the effect of inspirational motivation leadership practices on students' academic achievement. Teachers and students were tasked to indicate their agreement or disagreement on a likert scale that contained 9 key behaviours that constituted indicators of inspirational motivation leadership behaviour in this study. The behaviours were, the head of the school: recognizes and celebrates school's academic accomplishments and acknowledges failures, talks enthusiastically about the academic objectives of the school that needs to be accomplished, ensures that staff members enjoy working in groups/teams to enhance teaching and learning, secures teachers consent on important issues that connect students' academic performance before implementation, has confidence that teachers and students will accomplish challenging academic goals, consults students representatives on issues relating to academic progress of students, ensures that his actions are clearly understood by teachers and students in whatever he does that relates to academic progress of students, exhibits commitment to the academic goals of the school, and aligns individual goals with the goals of the school.

Teachers and students agreed that heads of schools practice the behaviours in the statements above, except one. Teachers weighted average for the statement: secured staff consent on important issues that connect students' performance before implementation was 3.4. Students' weighted average was 3.8. The explanation for this difference was lodged in the different expectations of the head of the school held by teachers and students.

The inferential statistical calculations revealed that there was a significant positive correlation between inspirational motivation and students' academic achievement. The correlation coefficient was 0.249 at 0.01 level of significance. With a beta of 1.044, the OLS regression analysis on the effect of inspirational motivation on students' academic achievement showed that there was significant positive effect of inspirational motivation leadership practices of school heads on students' academic achievement.

The study concludes that the following practices that constituted indicators of the inspirational motivation leadership behaviour were part of the leadership behaviours of heads of SHS in the Kumasi metropolis. The practices were : the school heads recognized and celebrated the schools' academic accomplishments and acknowledged failures, they enthusiastically spoke about the academic objectives of the school that needed to be achieved, ensured there was team work to promote teaching and learning, had confidence that staff and students will accomplish challenging academic goals, consulted students' representatives on academic issues, ensured his actions and deeds were understood, exhibited commitment to the academic goals of the school, and aligned individual goals with the goals of the school.

On the behaviour of securing teachers' consent on important issues that connects students' performance, the study concludes that teachers perceive their heads of schools as not engaging in this behaviour. However, students were of the opinion that teachers consent was sought by school heads on important academic issues before implementation.

Furthermore, the study concludes there is a significant correlation between inspirational motivation leadership behaviours and students' academic achievement. The study also concludes that there is a significant positive effect of inspirational motivation leadership behaviours on students' academic achievement.

This study recommends that school heads:

I. Should be talking happily about the academic goals of the school that need to be realized

II. Should recognize and celebrate the academic successes of the school and at the same time acknowledge failures of the educational institution.

III. Should demonstrate commitment to the academic goals of the school.

\section{REFERENCES}

Amin, M., E. (2005) Social science research: Conception, methodology, and analysis. Kampala: Makerere University

Asare, K. B. (2016). Are basic school head teachers transformational leaders? Views of teachers.African Journal of Teacher Education.Vol. 5. No. 1 (2016)

Ayiro, L. P. (2014). Transformational leadership and school outcomes in Kenya: Does emotional intelligence matter? FIRE: Forum for International Research in Education Retrieved from 
http://preserve.lehigh.edu/fire/vol1/iss.1/4

Bass, B.M. (1985). Leadership and performance beyond expectations. New York: Free Press

Berkovich, I. (2016). "School leaders and transformational leadership theory: time to part to ways?" Journal of Educational Administration, Vol. 54, pp 609-622, Retrieved from https://doi.org/10.1108/JEA-11-20150100

Boateng, I. (2014). A quantitative case study of transformational leadership characteristics of Valley View University of Ghana. Retrievehttps://digitalcommons.andrews.edu/cgi/viewcontent.cgi?

Bosman, A. (2015). The relationship between student academic achievement and student learning styles in a multicultural senior school. Retrieved from www.pdfdrrive.net

Burns, J. M. (1978). Leadership. New York. Harper \& Row

Creswell, J. W. (2012). Educational research: planning, conducting, and evaluating Quantitative and qualitative research. New Jersey: Pearson Prentice Hall.

Creswell, J. W., \& Plano Clark, V. L. (2011). Designing and conducting mixed methods Research (2nd ed.). Thousand Oaks, sage Publications, Inc.

Cruickshank, V. (2017).The influence of school leadership on student outcomes. Research Gate Retrieved from https://www.researchgate.net/.../319675066

Day, C. \& Sammons, P. (2015).Successful school leadership. Education Development Trust. Retrieved from www.educationdevelopmenttrust.com

Dhuey, E., \& Smith, J. (2014). How Principals influence student learning. Retrieved fromhttp://ftp.iza.org/dp7949.pdf

Fraenkel, J. R., Wallen, N. E., Hyun, H. H, (2012). How to design and evaluate research in education. McGrawHill companies, New York

Grant, C. \&Osanloo, A. (2014). Understanding, selecting, and integrating a theoretical framework in dissertation research: Creating the blueprint for your house. Administrative Issues Journal: Connecting Education, Practice, and Research. Doi: 105929/2014.4.2.9

Greenacre, L., Tung, N. M., \& Chapman, T. (2014). 'Self-confidence and the ability to influence. Academy of Marketing Studies Journal, 18(2), 169-180

Hallinger, P. (2003). School leadership development: global challenges and opportunities in: P Hallinger (Ed). Reshaping the landscape of school leadership development: a global perspective. (Lisse, Netherlands, Swets\&Zeitlinger)

Hildebrand, J. (2012). New ways to teach: Focused national standards are changing L1 classrooms. Newsday p.A02

Hughes, C., \& Jones, D., (2010-2011). A relationship among, ethics, and public school leadership, ethics, and student achievement.National Forum of Educational Administration and supervision Journal, 27(2). 50-73

Kayode, B. K., Mojeed, A. Q. \& Fatai, I. A. (2014). Leadership and decision-making :A study on reflexive relationship between leadership style and decision-making approach. sBritish Journal of education, Society and Behavioural Science 4(4): 473-484

Kimani, G. N., Kara, A. M., Njagi, L. W. (2013). Teacher factor influencing students' academic achievement in secondary schools in Nyandarua County, Kenya. International Journal of Education and Research, 1 (3)

Kothari, C. R. (2013). Research methodology: Methods and techniques (2nd Ed). New Age International (P) Ltd. Publishers. India

MeenuDev (2016). Factors affecting the academic achievement: A study of elementary School students of NCR Delhi, India. Journal of Education and Practice, Vol. 7, No.4. Retrieved from www.iiste.org

Mendels, P. (2012). The effective principal. Retrieved from www.learningforward.org

Mwangi, R. (2016). Impact of school leadership on academic achievement in Kenya Secondary schools.Retrieved from http://www.researchgate.net/publication/299536641.

Northouse, P. G. (2016). Leadership: Theory and practice. (7th Edition). Thousand Oaks,CA. Sage

Osagie, R. O., \& Momoh, U. (2013).Principals' leadership and student performance in Senior Secondary schools in Edo State, Nigeria. Educational Planning, Vol. 23, No. 3

Owen, K. M. \& Keller, S (2018).Exploring workforce confidence and patient experiences: A quantitative analysis. Patient Experience Journal (5) 1, 97-105

Ozen, S. O. (2017). The effect of motivation on students' achievement (Chapter 3). Retrieved https://www.researchgate.net/.../317178099

Rabgay, T. (2018).A study of factors influencing students' academic performance in a High secondary school in Bhutan. Retrieved from https://www.researchgate.net/.../326146681

Steinmayr, R., Meibner, A., Weidinger, A. F., \&Wirthwein, L. (2015).Academic Achievement. Retrieved from www.oxfordbibliographies.com/view/document doi: 10.1093/030/9780199756810-0108

Tripathy, M \& Srivastava, S. K. (2012).To study the effect of academic achievement on the level of selfconfidence.International Journal of Yoga and Allied sciences. (1) 1 
Tschannen-Moran, M. \& Tschannen-Moran, B. (2011). Taking a strengths-based focus improves climate. Journal of School leadership, 21(3) 422-448

Vidoni, D., \& Grassetti, L (2008). The role of school leadership on students' achievement: Evidence from Timms2003 Retrieved from https://www.iea.ni/sites/default/files/irc//IRC2008_Vidoni_Grassetti

Yukl, G. (2006). Leadership in organizations (6th Ed.). Prentice Hall, USA 'West African Examinations Council releases results', Daily Guide, Monday, August 25, 2014,pp 7 